This work is licensed under a Creative Commons Attribution 4.0 International License.

Ovaj rad dostupan je za upotrebu pod međunarodnom licencom Creative Commons Attribution 4.0.

https://doi.org/10.31820/f.30.2.2

Josip Parat i Petra Šoštarić

\title{
DUDIĆEV LATINSKI PRIJEVOD RASPRAVE O TUKIDIDOVU ZNAČAJU DIONIZIJA IZ HALIKARNASA
}

Josip Parat, mag. educ., Hrvatski institut za povijest - Podružnica za povijest Slavonije,

Srijema i Baranje, josip.parat@gmail.com, Slavonski Brod dr. sc. Petra Šoštarić, Filozofski fakultet, psostari@ffzg.hr, Zagreb

izvorni znanstveni članak

UDK 821.12.09Dionysius Halicarnassensis

rukopis primljen: 9. 10. 2018.; prihvaćen za tisak: 15. 11. 2018.

U radu se obrađuje ogled naslova De Thucydidis historia iudicium. Riječ je o latinskom prijevodu djelomično sačuvane rasprave O Tukididovu značaju

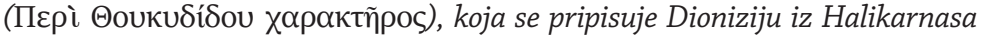
(1. st. pr. Kr. - 1. st. po Kr.). Prijevod je načinio humanist Andrija Dudić (1533. - 1589.), a otisnut je 1560. u Manuzijevoj tiskari u Veneciji. Grčko-rimski povjesničar i retoričar ondje je prikazao Tukididovu Povijest Peloponeskog rata kao ogledan primjer atičkogjezičnog izraza. Dionizije je i sâm uspješno oponašao slavnog Atenjanina i time poticajno djelovao na kasnije pisce. Iako ga je hvalio zbog obračuna s mitologiziranjem povijesnih djela, Halikarnašanin nije skrivao kritički ton spram nekih Tukididovih postupaka. Na tragu čitanja Tukidida i Dionizija, u radu se najprije skicira kulturno-povijesna uloga originalnog djela. Zatim se obrađuje recepcijska sudbina obojice pisaca. U središnjem dijelu rada iznesena je filološka obrada Dudićeva latinskog prijevoda. Cilj članka jest prikazati Dudićev rad u okviru recepcije obojice antičkih pisaca i u kontekstu renesansnog prevođenja s grčkog na latinski te analizirati Dudićeve prevodilačke postupke.

Ključne riječi: Dionizije iz Halikarnasa; Tukidid, Andrija Dudić; recepcija antike; humanizam; prevođenje s grčkog na latinski 


\section{Andrija Dudić}

Humanist Andrija Dudić (Andreas Dudithius Sbardellatus) rođen je 1533. ${ }^{1}$ U bijegu pred Turcima njegova je obitelj napustila imanje pokraj Drave i preselila se u Budim. U dobi od osam godina Dudić je izgubio oca te je brigu o njemu preuzeo ujak Augustino Sbardellato, utjecajni državni i crkveni dužnosnik talijanskog podrijetla koji ga je poslao na školovanje u Wrocław, a kasnije u Italiju (Almási 2009: 239). Dudić je proveo niz godina $\mathrm{u}$ inozemstvu, često u društvu utjecajnih ličnosti poput venecijanskog tiskara Paola Manuzija i engleskog kardinala Reginalda Polea. Paolo Manuzio u pismu upućenom Gian Vincenzu Pinelliju spominje Pinellijeve kolege i prijatelje, prevodioca i grecista Mihaela Sofijana, Dudića i učenjaka Felicea Paciottija te hvali dobru atmosferu, učenost i prisnost tog malog akademskog kruga aktivnog u Padovi sredinom 16. stoljeća (Meschini 1981: 47). ${ }^{2}$ Dudić je u Padovi upoznao i brojne poljske humaniste i pridružio se grupici učenjaka i humanista zvanoj contubernium Polonorum. Pripadali su joj, između ostalih, tiskar Jan Zamoyski, filolog Andrzej Patrycy Nidecki te pravnik Marian Leżeński, a bliski su im bili Carlo Sigonio i već spomenuti Manuzio (Facca, Lepri 2016: 84-85). Grupa je pokazivala osobitu naklonost prema Ciceronu: Nidecki je objavio zbirku Ciceronovih mudrih misli, a Zamoyski je tiskao nekoliko sličnih djela (Facca, Lepri 2016: 85-86). Važan izvor za poznavanje ovog kruga je Dudićeva prepiska s Manuzijem; potonji ih je prvi nazvao 'contubernium' (Facca, Lepri 2016: 84). ${ }^{3}$

Nakon smrti Augustina Sbardellata Dudićev pokrovitelj postao je Nikola Olah, ostrogonski nadbiskup, koji je zatražio od štićenika da privede studij kraju i zaredi se. Dudić se morao pokoriti nadbiskupovoj volji te je 1560 . postao njegov tajnik (Almási 2009: 244-245). Iste godine mu posvetio svoj prijevod Dionizija iz Halikarnasa. ${ }^{4}$ Do 1563 . je uspio postati kninski, čanadski i pečuški biskup te steći titulu kraljevskog tajnika i savjetnika, a bio je i

1 Dudićev životni put ovdje je vrlo sažeto prikazan prema Almási (2009: 239-283) i Jurić (2018).

2 Po mišljenju Marcelle Grendler, Pinelli je bio vlasnik „možda i najbolje privatne knjižnice u Italiji u drugoj polovici 16. st." (Grendler 1980: 386). Pinellijev dom u Padovi, kamo se doselio 1558., privlačio je brojne europske intelektualce kojima su bili na raspolaganju Pinellijeva bogata knjižnica te zbirka znanstvenih pomagala i građe za proučavanje (Grendler 1980: 387).

3 Facca i Lepri proučavaju njihovo bavljenje Ciceronom (Facca, Lepri 2016).

4 Kasnije izdanje je namjeravao posvetiti Marku Sinckmoseru, tajniku carske kancelarije (Almási 2009: 135-136). 
diplomat u službi Maksimilijana II. Sudjelovao je na Tridentskom koncilu 1562.-1563. (Almási 2009: 245-248). Almási smatra razdoblje Tridentskog koncila i dvije godine nakon njega vrhuncem Dudićeve karijere (Almási 2009: 282). Za vrijeme diplomatske misije u Poljskoj Dudić se 1567. u tajnosti oženio, zbog čega ga je papa sljedeće godine ekskomunicirao, a došlo je i do privremenog zahlađenja u odnosu s carem (Almási 2009: 257-259). Nakon nekoliko godina vraća se u diplomaciju, no za vladavine Rudolfa II. karijera mu ne doseže ranije visine (Almási 2009: 275-278). Posljednje godine života proveo je u Wrocławu gdje se bavio intelektualnim radom, no čini se da ni tamo nije bio u potpunosti zadovoljan (Almási 2009: 280). Umro je 1589.

U sačuvana djela ubrajaju se govori, brojna pisma, prigodne pjesme, latinski prijevod Beccatellijeve biografije Reginalda Polea (Vita Reginaldi Poli Britanni S. R. Ecclesiae Cardinalis et Cantauriensis archiepiscopi, 1563.), prirodoznanstvena rasprava De cometarum significatione commentariolus (1579) te već spomenuti prijevod Dionizija iz Halikarnasa. ${ }^{5}$ Sudeći po općem tonu Dionizijeva spisa, glavna misao vodilja je $\mu$ í oponašanje klasičnog uzora. U tome - vidjet ćemo - leži i razlog humanističkog zanimanja za ovaj spis.

\section{Dudićev prijevod Dionizija iz Halikarnasa}

Dudićev prijevod Dionizija iz Halikarnasa bio je cijenjen od suvremenika (Almási 2009: 286). Doživio je nekoliko izdanja. Prvo je objavljeno u Manuzijevoj tiskari: Dionysius Halicarnassensis. De Thucydidis historia iudicium. Andrea Duditio Pannonio interprete, Venetiis, 1560. Ponovno je objavljeno u Veneciji 1571. pod naslovom Qua ratione, via, ac methodo, historias cum Latinas, tum praesertim Graecas, intelligenda, iudicanda et legenda sint. Opus eruditissimum ac omnibus historiographis, multo Pernecessarium. Dionisio Licarna (sic). Authore. Slijedila su izdanja u Baselu 1576., 1579. i 1636., Sylburgovo u Frankfurtu 1586., Hudsonovo u Londonu 1704. te Reiskeovo u Leipzigu 1777. ${ }^{6}$ Zaslužni proučavatelj Dudićeve ostavštine, Pierre Costil, u

5 Popis djela dostupan je na stranicama Instituta za filozofiju (http://content.ifzg.hr/ digitalnaBastina/digitalnaBastinaAndreasDuditius.htm), gdje se može naći i digitalizirano izdanje rasprave De cometarum significatione commentariolus, te u Costilovoj studiji (Costil 1935: 387-403).

6 Popis izdanja preuzet s http://content.ifzg.hr/digitalnaBastina/digitalnaBastinaAndreas Duditius.htm i Costil (1935: 387-388). Izdanje iz 1576. je dio zbirke Io. Bodini Methodus historica Duodecim eiusdem argumenti scriptorum tam veterum quam recentiorum commentariis 
dijelu svoje studije posvećenom Dudićevoj filološkoj aktivnosti govori i o prijevodu Dionizija iz Halikarnasa te navodi da je Dudić posjedovao grčki rukopis teksta koji mu je dao Paolo Manuzio, a koji je danas izgubljen. Postoji, međutim, sedam rukopisa pomoću kojih se može doći do nekih zaključaka o tekstu koji su Dudić i Manuzio imali na raspolaganju, tj. njegovom mjestu u rukopisnoj tradiciji (Costil 1935: 247-255). Dudićev latinski autograf (kojem je dodan i Dudićev prijepis odlomaka iz spomenutog Aldovog izdanja Tukidida), s ispravkama i napomenama unesenim Dudićevom i Manuzijevom rukom čuva se u venecijanskoj knjižnici Marciani (lat. XIII, 118) kamo je stigao kao dio zbirke bibliofila Giacoma Morellija (Costil 1935: 235-236).

Rukopis od 77 listova dimenzija $29 \times 20,5 \mathrm{~cm}$ uvezan je u korice dimenzija $31 \times 22 \mathrm{~cm}$. Počinje samim prijevodom, a uvodna posveta Olahu nalazi se na fol. 4. bis recto. Ispravke i napomene pisane su na latinskom, talijanskom i grčkom. Latinske odlomke iz Tukidida, kojeg Dionizije izdašno citira, Dudić je preuzeo iz prijevoda Lorenza Valle i uključio u svoj prijevod (Costil 1935: 236). Manuzio je radio i na izdanju grčkog teksta, ali priredio je tek oko dvije petine (Costil 1935: 238).

Costil je izrazio pozitivno mišljenje o Dudićevom prijevodu, ali se nije posebno bavio Dudićevim prevodilačkim načelima i postupcima, niti njegovim vokabularom, no smatrao ga je boljim prevodiocem od Manuzija koji je po njegovom mišljenju previše skraćivao (Costil 1935: 235-236). Zato ćemo ih ovdje podrobnije prikazati na odabranim primjerima, uz osvrt na Manuzijeve ispravke i Costilovu ocjenu. ${ }^{7}$

\section{Dionizije iz Halikarnasa}

Dionizije iz Halikarnasa, povjesničar i retoričar druge polovice 1. st. pr. Kr., ubraja se među poznatije antičke pisce. ${ }^{8}$ Njegov životni vijek poklapa

adacta... Basileae ex Petri Pernae officina. Dudićev tekst nije potpun (Costil 1935: 387-388). Izdanje iz 1579. je Dudićev prijevod objavljen kao dio prvog sveska zbirke Artis historicae penus u kojem se nalazi još sedam rasprava o pisanju historiografije. Ova je zbirka zapravo prošireno izdanje one iz 1576. (Costil 1935: 387-388).

7 Grčki tekst citiran je prema Loebovom izdanju, a latinski, ako nije navedeno drugačije, prema venecijanskom iz 1560.

8 Za detaljne biografske podatke v. enciklopedijsku natuknicu u Dessau (1897: D88); Schwartz (1905: 934-961); Jacoby (1957: 1146-1151). Iscrpan pregled Dionizijevih književnih postupaka nudi De Jonge (2008). 
se s turbulentnim razdobljem u kojem se rimska država našla na smjeni republikanskog i monarhijskog uređenja. Poput niza učenih Grka toga doba, Dionizije je najplodnije stvaralačke godine proveo u prijestolnici, u blisku doticaju s nositeljima političkog i kulturnog života. U Staroj rimskoj

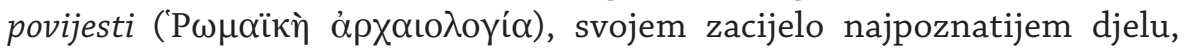
prikazao je razvitak Rima od mitskih začetaka do Prvoga punskoga rata. ${ }^{9}$ Leksikografski priručnici pripisuju mu više retoričko-kritičkih studija: $O$

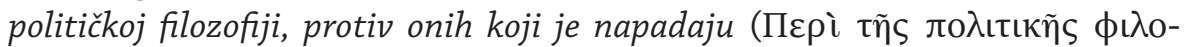

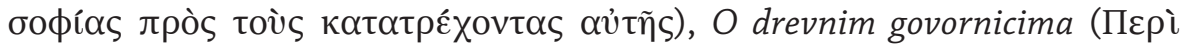

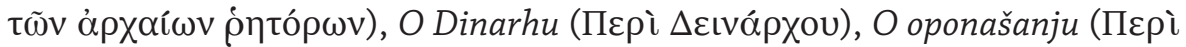

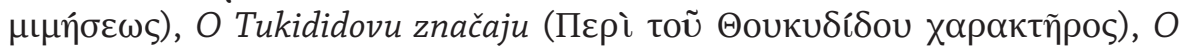

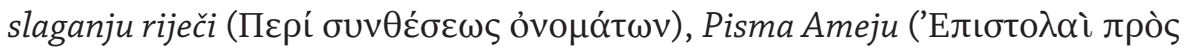

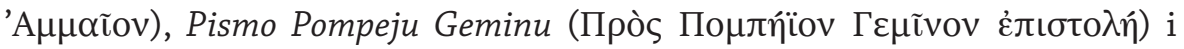

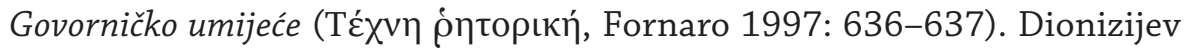
književni rad odvijao se u okrilju aticizma. Nastao u krugu helenističkih autora, aticistički pokret bio je reakcija na bujnost azijskog govorničkog stila i težio je povratku na jednostavan klasični jezik. ${ }^{10}$ Dionizije je pribjegavao takvom izrazu, vodeći računa o dosljednom oponašanju starih pisaca. Uz govornika Demostena, veoma je cijenio povjesničara Tukidida, o čemu svjedoči ogled O Tukididovu značaju, kronološki posljednji Dionizijev spis. Riječ je o samo jednom u nizu sastavaka koji su tumačili Tukididovu Povijest Peloponeskog rata (dalje: Povijest; 5. st. pr. Kr.) i ocjenjivali njegove spisateljske postupke. ${ }^{11} \mathrm{U}$ svrhu razumijevanja uloge latinskog prijevoda ovoga djela, valja razložiti sadržaj Dionizijeva grčkog izvornika i prikazati Tukididov utjecaj na antičke i humanističke pisce.

\section{O Tukididovu značaju}

Ogled O Tukididovu značaju koncipiran je kao vrlo dugo pismo od šezdesetak kartica teksta. ${ }^{12}$ Počinje pozdravom rimskom povjesničaru Eliju

\footnotetext{
9 O Dioniziju kao povjesničaru v. Gabba (1991); Fromentin (2001).

10 Podrobnije o aticističkom stilu v. u Schmid (1887-1896); Norden (1898: 344-416); Reardon (1971: 81-96); Wisse (2001: 65-82).

11 Za obuhvatnije analize Dionizijevog spisa v. Grube (1950: 95-100), Irwin (2015).

12 Za potrebe ovoga rada korišteno je izdanje Usher (1974). Godinu dana nakon ovog izdanja izašla je prva komentirana edicija (Pritchett 1975).
} 
Tuberonu i svima koji će oponašati slavnog Atenjanina (De Thuc. 1 ; 25). ${ }^{13}$ Objasnivši razloge za kritiku (pogl. 1-4), Dionizije kratko raspravlja o Tukididovim prethodnicima (5-6) te o njegovu poimanju historiografije (7-8). Središnji dio zauzimaju komentari o sadržajnim (9-20; 28-51) i stilskim obilježjima (21-27), dok se na koncu sažeto obrađuju Tukididovi oponašatelji (52-55). Čitajući ogled O Tukididovu značaju, stječe se dojam da je Dionizije bio itekako svjestan poteškoća što su pratile antičke povjesničare. ${ }^{14}$ Prema jednoj računici, Dionizije je u ovome radu citirao Tukidida ukupno 69 puta (Pritchett 1957, xvi). Pritom su najučestaliji ulomci iz 1. i 2. knjige, u kojima se nalazi najviše govorâ što ih je Tukidid stavio u usta ratnim akterima.

Za razumijevanje humanističke recepcije Tukidida osobito je važan Dionizijev komentar iz središnjeg dijela rasprave. Dionizijeva kritika Tukidida proteže se od ispitivanja pojedinih riječi, fraza i rečeničnih konstrukcija pa do zamršenih pitanja stila i usklađenosti čitava djela (9). Kritičar najprije hvali Tukidida jer je - za razliku od ranijih prozaika koji su se uglavnom bavili lokalnom poviješću ili od Herodota koji je zahvatio preširok prostor i vrijeme - našao pravu mjeru, pripovijedajući o važnoj, a kronološki nevelikoj epizodi (6). Potom upozorava čitatelje na neke problematične aspekte Povijesti (9). Pored toga što se na meti našlo Tukididovo pripovijedanje po zimama i ljetima (10), Dioniziju je zasmetalo i to što je povjesničar najprije razložio navodne, a tek potom istinske uzroke Peloponeskog rata (11). Zatim mu predbacuje detaljne opise sporednih zbivanja i štur prelazak preko bitnih događaja (13). Slično je i s govorima: prema Dionizijevu sudu (16-18), Tukidid ih je umetao i kamo nije trebalo, dok su na nekim mjestima - primjerice, u 8. knjizi - posve izostali. ${ }^{15} \mathrm{U}$ tom smislu osobito se okomio na Periklov nadgrobni govor u čast poginulih Atenjana (usp. Thuc. II, 3646). Govor se, smatra kritičar, našao na pogrešnom mjestu, neposredno nakon kratkih i nepovezanih prizora koji su nevažni za slijed radnje.

13 Inače, Dionizijev adresat i suvremenik, netom spomenuti Kvint Elije Tuberon bio je na glasu kao političar i povjesničar, vrstan poznavatelj klasične književnosti. Podrobnije o njemu v. Peter $\left({ }^{2} 1914\right.$ : 311-315).

14 Tukidid je, naime - što eksplicitno, što između redaka - na više mjesta uputio na poteškoće na koje je naišao tijekom prikupljanja građe i sastavljanja spisa (usp. Thuc. I, 20; I, 22, 4; $\mathrm{V}, 20,2-3)$.

15 Tako i Dionizije, kada citira Tukidida, najviše citira govore. Budući da oni u 8. knjizi izostaju, ni Dionizije ne donosi nijedan komentar iz tog odsječka Povijesti. 
I ovako kratak pregled nudi dva moguća zaključka. S jedne strane, Dionizije je izvrgnuo strogoj - gdjekad i prestrogoj - prosudbi povjesničara kojega je inače oponašao. $S$ druge strane, čini se kao da su autori zamijenili uloge, pa Dionizije ovdje nastupa kao povjesničar, a Tukidid kao retoričar. ${ }^{16}$ Predbacujući Tukididu stilske nedostatke, Halikarnašanin kao da namjerno propušta uzeti u obzir pravu namjeru Tukididove Povijesti koja je prije svega trebala potaknuti čitatelja na razmišljanje o velikim djelima i ljudskoj prirodi.

Pa ipak, Dionizije je znao i pohvaliti Tukididov stil, osobito kad je riječ o opisu Sicilske ekspedicije (Thuc. VII, 69-72, Dion. Hal. Thuc. 26-27) ili o govorima istaknutih pojedinaca (Dion. Hal. Thuc. 27). ${ }^{17}$ Ondje mu priznaje pjesnički ali ozbiljan izričaj, strastveno pripovijedanje, raznoliku uporabu figura i izražajnu moć: na primjer, u govoru o Platejcima (42). U zaključku savjetuje čitateljima da što više oponašaju Tukidida. Poput drugih retoričkih sastavaka, i ovaj ukazuje budućem govorniku na prednosti i mane staroga pisca; upućuje što kod Tukidida valja nasljedovati, a što izbjegavati.

\section{Recepcija Tukidida i Dionizija iz Halikarnasa}

Tukidid je još od antike imao brojne poklonike. Jedni su - na primjer Ksenofont i Teopomp - nastavili pisati gdje je on stao, dok su ga drugi poput Dionizija i Lukijana - smatrali uzorom za sve buduće historiografske sastavke. ${ }^{18}$ Antički i moderni kritičari cijenili su Tukididovo bavljenje uzrocima zbivanja, nepristran sud, rad na izvorima, odbacivanje mitova i praktičnu korisnost (Pade 2003: 103-181). Prema običaju starovjekovne historiografije, autori su aludirali na slavna mjesta iz Tukididove Povijesti, rabili njegove citate i stilska sredstva. Znali su preuzimati i čitave odlomke (poglavito govore i opise bitaka), a da i nisu uvijek navodili njihovo pod-

16 Drugi zaključak već su iznijeli raniji istraživači. Usp. Usher (1974: 457).

17 Unutar antičkog promišljanja o stilu Dionizije je Tukididu namijenio uzvišeni stil

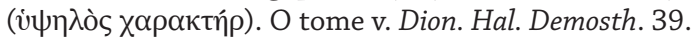

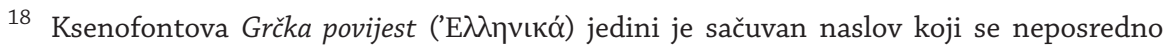
nadovezuje na Tukididovu građu, obuhvaćajući zbivanja od 411. pr. Kr. do bitke kod Mantineje 362. pr. Kr. Teopomp se također nastavljao na Tukidida u nesačuvanoj Helenskoj

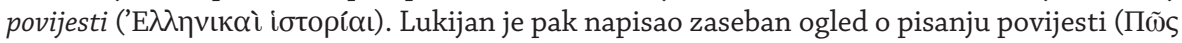

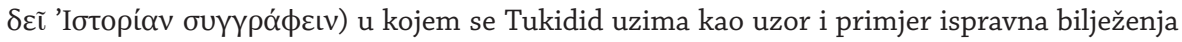
prošlih događaja. Opširnije o Tukididovim nasljedovateljima v. Grayson (1975); Riedinger (1991); Parker (2001); Nicolai (2006). 
rijetlo. ${ }^{19}$ Promjenom društveno-političkih prilika na razmeđu dviju erâ Tukididova Povijest počela se koristiti na drugačiji način: više nije služila samo kao vojno-politički priručnik, već se mogla shvaćati i kao zgodno sročena retorička zbirka. Ipak, povjesničar bi pritom u pravilu ostajao u sjeni antičkih govornika. Plutarh, recimo, navodi da se Katon Stariji „okoristio u govorništvu malo Tukididom a više Demostenom”. ${ }^{20}$ Ciceron je pak visoko cijenio Tukididov historiografski angažman, no ipak ga je propustio ubrojiti u majstore govorničkog umijeća. ${ }^{21}$ Među Rimljanima, povjesničar Salustije uživao je glas Tukididova sljedbenika, o čemu svjedoče njegove digresije o ljudskoj prirodi, javni govori, ali i stilski postupci, osobito sklonost antitezama. ${ }^{22}$ Pisci grčkog jezika također su nasljedovali Atenjanina: Dionizije iz Halikarnasa, na primjer, mimo rada kojim se ovdje bavimo, rasprav-

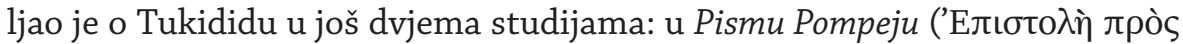

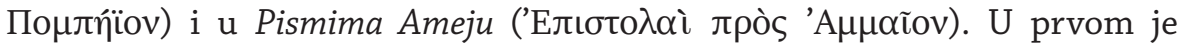
usporedio Tukididove teme, strukturu i stil s Herodotovima, a u drugom se bavio njegovim leksikom.

Europski humanisti upoznali su Tukidida i Dionizija nekoliko desetljeća uoči pada Carigrada. Iako su središta humanističke naobrazbe raspolagala nizom bizantskih rukopisa obojice autora, slabo poznavanje starogrčkog ograničilo je njihovu uporabu. Malobrojni humanisti koji su se snalazili u spisima na grčkom oblikovali su vlastita povijesna djela na Tukididovim temeljima, prenoseći tako zasade helenske historiografije. To se manifestiralo na dva načina: osim što su njihovi radovi, po uzoru na antičke, imali snažnu pripovjednu notu, pisali su o egzemplarnim likovima i postupcima koje vrijedi oponašati.

Prvi humanist koji je uspješno nasljedovao Tukidida bio je Leonardo Bruni (o. 1370-1444; Cochrane 1981: 3; Ianziti 2012: 94). Poput Atenjanina, Bruni je iz Povijesti firentinskog naroda (Historiarum Florentini populi libri XII) izostavio legende o osnutku grada i odbacio tumačenja o nadna-

19 U helenističko doba nasljedovali su ga Polibije (2. st. pr. Kr.) i Posidonije (2./1. st. pr. Kr.): prvi najviše u sastavljanju govorničkih dionica, a drugi u uvodnom dijelu svoje povjesnice.

20 Preveo Z. Dukat; Cat. Ma. 2.5.

21 Naredna formulacija možda je najrječitija potvrda njegov stava: Thucydidis enim quidam eloquentiam admirantur. Id quidem recte; sed nihil ad eum oratorem quem quaerimus. (Cic. Opt. gen. 15). Usp. Orat. 30; Brut. 287.

22 Više o Salustijevu nasljedovanju Tukidida v. u Meister (2016). 
ravnom utjecaju u povijesno kretanje. Što se pak tiče prevođenja Tukididove Povijesti na latinski, tijekom 15. st. objavljivali su se mahom kraći ulomci koji prikazuju neku glasovitu epizodu Peloponeskih ratova. Pionirske pothvate pritom su ostvarili Lorenzo Valla (1407-1457), autor prvog cjelovitog prijevoda (1452), i Aldo Manuzio (1449-1515), priređivač prvog tiskanog izdanja grčkog izvornika (početak 16. st.; Pade 2003: 120-128). Premda se nedugo potom pojavilo više inačica na narodnim jezicima, i dalje su se priređivali manji odlomci na latinskom.

Među renesansne humaniste koji su se bavili Tukididom i Dionizijem ubraja se i Andrija Dudić. Čini se da se Dudić bavio ovim autorima više iz retoričkih nego iz historiografskih pobuda. ${ }^{23}$ I drugi su renesansni prevoditelji u historiografiji nalazili zalihu dobrih spisateljskih rješenja, tek prigodice vodeći računa o namjeni originalnih sastavaka. $O$ tome svjedoče brojni tematski izvaci europskih humanista. Neki autori tih izvadaka pripadali su Dudićevu krugu. Među njima je bio i Philipp Melanchthon (1497-1560). On je u Wittenbergu preveo 35 Tukididovih govora za potrebe nastave (Pade 2003: 136). Pritom je osobito zanimljivo da je u uvodu opsežno citirao Dionizijeve, Ciceronove i Kvintilijanove opaske o Tukididovu stilu, s naglaskom na govorima. ${ }^{24}$ Osim toga, Joachim Camerarius (1500-1574) dvadeset godina prije Dudića izdao je latinski prijevod Tukididova predgovora za Povijest Peloponeskog rata, kao i Periklov nadgrobni govor, poprativši sve zajedno opsežnim komentarima.

Svjestan tadašnjeg ograničena poznavanja grčkog te imajući na umu činjenicu da sudovi antičke kritike pomažu u razumijevanju Tukidida, Dudić se opredijelio za prevođenje Dionizijeva komentara. Latinska inačica nije morala biti namijenjena samo oponašateljima Tukididova stila ili autorima što su tražili latinske ekvivalente njegovih izraza, već i potencijalnim historiografima.

23 O recepciji Tukididova djela u renesansi v. Pade (2015).

24 Tukidid je, prema njemu, radije htio prikazati sukob pravde i nepravde nego rat dvaju vodećih polisa klasičnog doba. 


\section{Dudićev predgovor prijevodu}

U predgovoru koji ćemo ovdje sažeti Dudić posvećuje djelo Nikoli Olahu. ${ }^{25}$ Govori o važnosti pisanja povijesti: nijedna druga aktivnost ne donosi ljudima toliku slavu, čak ni borba za vlastitu domovinu. Navodi niz važnih ličnosti antičkog svijeta (Tukidida, Ksenofonta, Hanibala, Katona, Sulu, Lukula, Cezara, Augusta, Hadrijana i Gordijana) koji su ujedno bili i vojskovođe, ali koji se nisu zadovoljili osvajanjima, pobjedama i trijumfima, nego su povrh svega svoje pothvate i opisali u prozi. ${ }^{26} \mathrm{Za}$ uspješno pisanje historiografije potrebno je i teoretsko znanje, ne samo ratno iskustvo koje se opisuje. Nakon općenitog uvoda Dudić prelazi na Dionizija. Po Dudiću, Dionizije iz Halikarnasa vrhunski je poznavalac povijesti i izrazito strog kritičar. Kad bismo ocjenjivali Tukidida po Dionizijevim kriterijima, Tukidid više ne bi bio na prvom mjestu među povjesničarima, nego na zadnjem, konstatira Dudić, no Dionizijevi komentari mogu biti od velike koristi svima koji se žele baviti historiografijom. ${ }^{27}$ Dudić spominje (i hvali) Manuzija koji mu je dao tekst pod uvjetom da ga prevede na latinski. Kao što je uobičajeno u humanističkim predgovorima uz prijevode, Dudić iznosi svoj prevodilački credo: grčki jezik daleko nadmašuje latinski bogatstvom i ljepotom pa je teško uvijek jasno prevoditi. Dudić je cijenio elegantan i dotjeran prijevod te je izbjegavao prevoditi po načelu „riječ za riječ”, ad verbum, već se trudio vagati smisao (non ut verba vitandi laboris gratia, singula singulis reddens, annumerarem, sed ut sententias ipsas appenderem „, ne da nabrajam riječi da izbjegnem napor, prevodeći pojedinačne riječi pojedinačnima, već da odvagnem same misli"). Iako ne spominje izrijekom Cicerona, izborom riječi legitimira se kao njegov sljedbenik te aludira na Ciceronovu misao non enim ea me adnumerare lectori putavi oportere, sed tamquam appendere "nisam naime mislio da ih čitatelju trebam nabrajati, već takoreći odvagnuti" (Cic. Opt. Gen. 5.). ${ }^{28}$ Postavlja se pitanje zašto Dudić nije izrijekom spomenuo Cicerona. Moguće je da je smatrao citat toliko poznatim da nije potrebno navesti izvor, ili da je po sjećanju citirao misao autora čijeg imena se u trenutku pisanja nije mogao sjetiti. Zbog Cicero-

\footnotetext{
25 Dionysius Halicarnassensis. De Thucydidis historia iudicium. Andrea Duditio Pannonio interprete, Venetiis, 1560, [1-15].

26 Rimski vojskovođa Lucije Licinije Lukul (2.-1. st. pr. Kr.) bio je autor historiografskog spisa Povijest marsijskog rata, a rimski car Gordijan (2.-3. st.) epa Antoninijada.

27 Dionysius Halicarnassensis, o. c., [8].

28 Ea se odnosi na verba.
} 
novog utjecaja na humanističko obrazovanje (i osobit interes za Cicerona u Dudićevu padovanskom krugu) smatramo vjerojatnijom prvu mogućnost. Ciceronova rasprava $O$ najboljoj vrsti govornika (De optimo genere oratorum) danas se smatra jednim od najvažnijih priloga antičkoj teoriji prevođenja, a uz njegova djela O krajnostima dobra i zla (De finibus bonorum et malorum) i O govorniku (De oratore) te Kvintilijanovo Obrazovanje govornika (Institutio oratoria) utjecala je na humanističke poglede na prevođenje (Hosington 2014: 127).

Pri kraju predgovora Dudić najavljuje daljnje objavljivanje prijevoda s grčkog. Zaključno se, uz još nešto kurtoaznih fraza, vraća Olahu koji i sam razmišlja o pisanju povijesti, i to ugarske (Dionysius Halicarnassensis 1560: $[11]) .^{29}$

\section{Traduktološka analiza}

U traduktološkoj analizi razmotrit ćemo odabrane ulomke Dudićeva teksta kojima ćemo ilustrirati njegov prevodilački stil s naglaskom na razlike između izvornika i prijevoda te razlike između grčkog i latinskog jezika koje su bile izazov prevodiocu. Dotaknut ćemo se i Dudićevog latinskog vokabulara.

\subsection{Dionizijevo uvodno obraćanje Kvintu Eliju Tuberonu}

Év

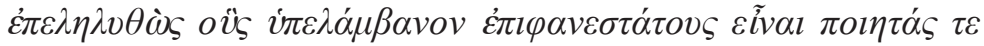

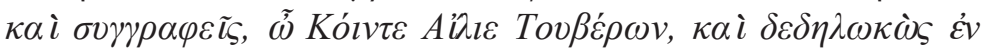

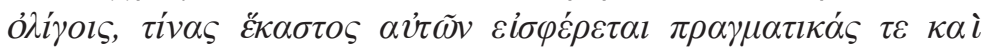

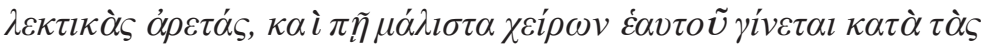

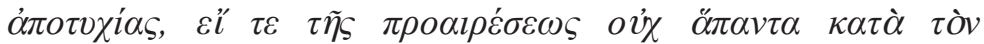

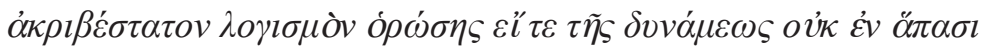

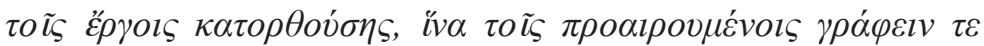

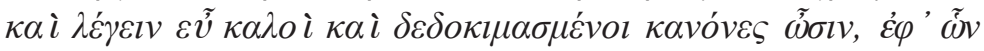

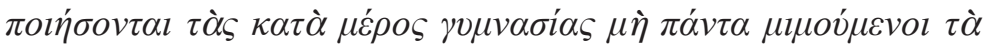

29 Olah je bio autor historiografskih djela Hungaria sive de originibus gentis, regni, situ, divisione, habitu atque opportunitatibus, Chronicon i Athila. Više o njemu donosi Castilia Manea-Grgin koja navodi da su djela Hungaria i Athila završena u Bruxellesu 1536.-1537. te su dugo kružila u rukopisu, a Chronicon objavljen 1558. kao predgovor djelu Breviarium (Manea-Grgin 2010: 240, 243). 


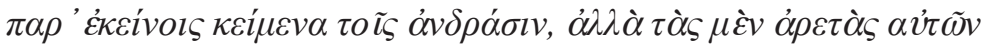

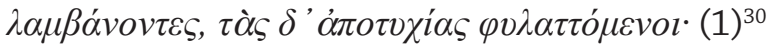

„U ranije objavljenim spisima o oponašanju raspravio sam o onima koje sam, Kvinte Elije Tuberone, smatrao najistaknutijim pjesnicima i prozaicima, i rastumačio sam ukratko koje vrline na planu sadržaja i stila donosi svaki pojedini od njih, i kako točno postaje lošiji od samog sebe po greškama: ili jer mu izbor nije uzeo sve u obzir na najprecizniji način, ili jer snaga nije u svim djelima polučila uspjeh; da bi oni koji odluče dobro i pisati i govoriti imali dobra i prokušana pravila, prema kojima će po redu vježbati ne tako da oponašaju sve što se nalazi kod onih ljudi, nego tako da preuzimaju njihove vrline, a čuvaju se njihovih grešaka."

In iis libris, Quinte Aeli Tubero, quos iam antea de imitatione conscriptos emisimus, tam de iis qui carmine, quam qui soluta oratione scripserunt, quos quidem praeter ceteros putavimus excellere, disseruimus; et quas quisque tum verborum, tum sententiarum virtutes haberet, breviter ostendimus. atque illud praeterea examinavimus, qua maxime in parte quisque a proposito aberrans, se ipso interdum factus deterior esse videatur: idque, sive quod, quae litteris mandaret, parum scienter delegerit, sive, quod vires ad praestandum defuerint. quae quidem omnia eo sumus aggressi, ut ii qui bene scribendi, beneque dicendi laudem sequerentur, rectam aliquam et probatam normam haberent, ad quam suas quocumque in genere exercitationes dirigerent; neque prorsus omnia, quae apud illos scripta reperiuntur, ad imitationem sibi proponerent; sed ex illis, si quae sunt dicendi virtutes, caperent, vitia vero studiose declinarent.

„U onim knjigama, Kvinte Elije Tuberone, koje smo ranije napisane o oponašanju objavili, raspravili smo kako o onima koji su pisali u stihu, tako i onima koji su pisali i prozi, a za koje smo pomislili da se ističu više nego ostali; i ukratko smo pokazali koje vrline izraza i sadržaja svaki ima. A osim toga

30 Brojevi označavaju paragrafe Loebovog izdanja. 
smo ispitali i ono, kojim dijelom bi se netko najviše udaljio od cilja i učinio da postaje lošiji od samog sebe: ili jer nije dovoljno stručno odabrao ono što piše, ili jer nije imao snage da obavi posao. A svega toga smo se prihvatili zato da bi oni koji teže pohvali za dobro pisanje i dobro govorenje imali nekakvo mjerilo, prema kojem bi uređivali svoje napore u kojem god žanru; i da ne bi pokušavali oponašati sve što se kod onih nalazi napisano, već da od njih preuzmu vrline izražavanja, ako ih ima, a mane da revno izbjegavaju."

Latinski odlomak za dva retka je duži od grčkog. Dudić je grčki tekst razlomio na nekoliko latinskih rečenica. Predikat $\dot{\varepsilon} \delta \eta ́ \hat{\lambda} \omega \sigma \alpha$ nalazi se u drugom dijelu rečenice navedenom pod 6.2. Ipak, Dudić već ovdje nekoliko

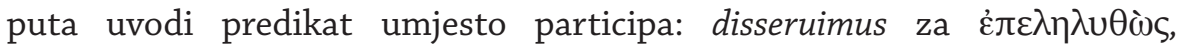

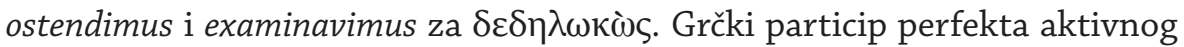
nije imao latinski ekvivalent pa je Dudić ponudio ovo rješenje, a u drugom slučaju ta intervencija ujedno olakšava čitatelju snalaženje u tekstu. Dodaje i rečenicu quae quidem omnia eo sumus aggressi, kojom rezimira prethodni dio i jasnije uvodi namjernu rečenicu. Uz examinavimus dodano je atque illud praeterea. Pretraživanje baze Perseus pokazuje da je riječima atque illud Ciceron rečenicu počeo 21 put, Aulo Gelije tri puta, Augustin jedanput. Osim što je postigao da latinski tekst bude manje zgusnut od originala, ovim dodavanjem približio ga je stilu rimske proze.

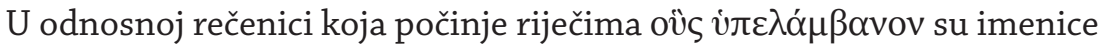

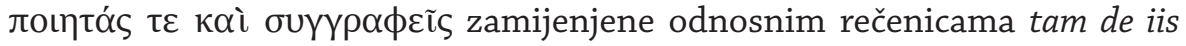
qui carmine, quam qui soluta oratione scripserunt iako bi se mogao ponuditi kraće i jednostavnije de poetis et scriptoribus (možda uz dodatak solutae orationis). Opreka tam... quam česta je u rimskoj književnosti te smatramo da je i ovdje Dudić želio razvedeniji, elegantniji tekst u duhu rimskih autora. Da Dudić nije uvijek prvenstveno želio proširivati pokazuje

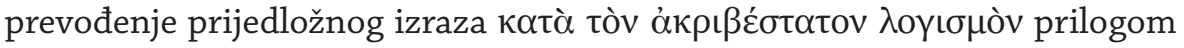
scienter koji je u korpusu rimske književnosti upotrijebljen samo 13 puta: po jedanput kod Amijana Marcelina i Cezara, dvaput kod Aula Gelija i devet puta kod Cicerona.

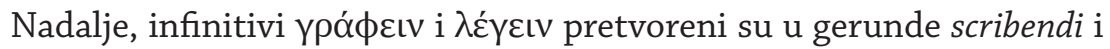
dicendi koji se nalaze u genitivu objekta uz imenicu laudem za koju nema ekvivalenta u grčkom tekstu. 


\subsection{Dionizije o sažetosti i kratkoći u svojim ranijim radovima o prozaicima}

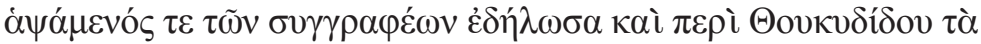

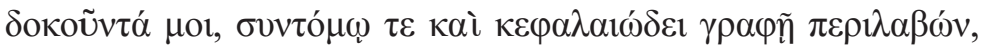

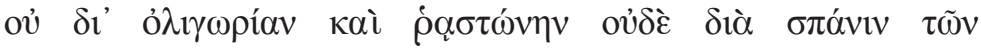

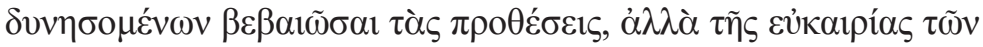

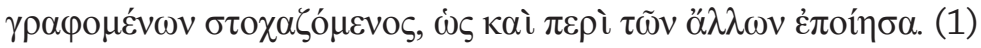

„Kad sam se pozabavio proznim piscima, objelodanio sam i svoje mišljenje o Tukididu, prikazavši ga kratkim i sažetim tekstom, ne zbog prezira i lijenosti niti zbog nedostatka onoga što može potkrijepiti tvrdnje, nego sam, težeći za prikladnošću napisanog, učinio kao i kod drugih."

Atque in illis quidem libris, cum de historicis non nulla attigissem, etiam ea quae mihi de Thucydide viderentur, ostendi. quae quidem omnia breviter et summatim sum complexus: non equidem negligentia, neque vero quod earum rationum, quibus propositum nostrum confirmare ac stabilire possemus, copia me deficeret; sed quia omnem meam scriptionem ad ea quae maxime opportuna esse, et ad rem facere viderentur, veluti ad scopum quendam, referebam. quod equidem institutum, cum de aliis etiam scriptoribus agerem, servavi.

„A u onim knjigama, kad sam se dotaknuo nekih stvari o povjesničarima, iznio sam i ono što mislim o Tukididu. To sam sve kratko i sažeto obuhvatio: naravno, ne iz nemara, niti mi je nedostajalo obilje onih argumenata, kojima bismo mogli potvrditi i poduprijeti našu tvrdnju; već zato što sam sve svoje pisanje, kao prema nekom cilju, usmjeravao prema onome što se čini da je najviše prikladno i doprinosi temi. To je načelo kojeg sam se svakako držao i kad sam se bavio drugim piscima."

Latinski prijevod opet je duži od grčkog originala. Particip aorista

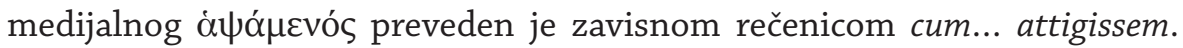
Budući da se latinski glagolski sustav nije poklapao s grčkim i broj participa u latinskom je bio znatno manji, Dudić je morao naći rješenje za ovaj oblik koji nije imao ekvivalent u grčkom. 


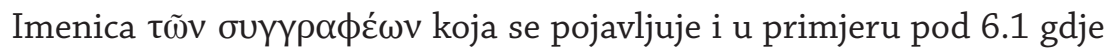
je prevedena qui soluta oratione scripserunt ovdje je prevedena jednom riječju, historicis. Imenica može značiti i „prozni pisac” i „povjesničar”. Moguće je da je Dudić svjesno odabrao dva različita prijevoda jer se u prvoj rečenici radi o opreci između poezije i proze, a u drugoj nije bilo takve opreke, ili da je jednostavno želio raznolikost u prijevodu. Početak rečenice $\mathrm{u}$ latinskom prijevodu, Atque in illis quidem libris, nije motiviran ničime u grčkom tekstu, ali kao priložna oznaka dopunjava predikat. Infinitiv aorista $\beta \varepsilon \beta \alpha \iota \tilde{\omega} \sigma \alpha \iota$ zamijenjen je dvama infinitivima prezenta confirmare ac stabilire.

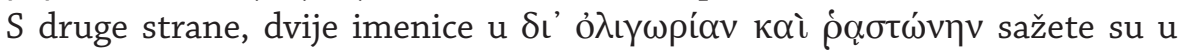

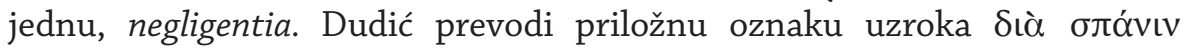
uzročnom rečenicom quod ... copia me deficeret. Umjesto da upotrijebi ablativ uzroka kao kod negligentia, Dudić se poveo za Cezarom kod kojeg nalazimo izraz copia defecit (Caes. Gal. 6.16.5).

\subsection{Dionizije ispunjava želju i održava riječ danu Kvintu Eliju Tuberonu}

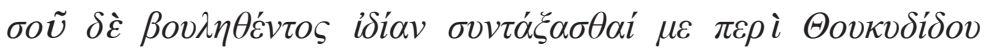

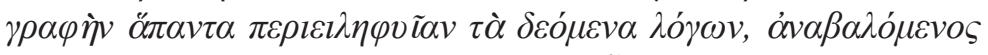

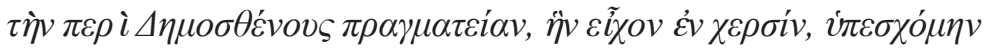

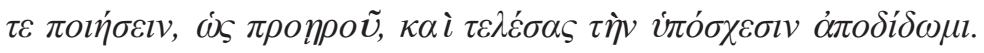
(1)

„Kad si poželio da sastavim poseban spis o Tukididu, koji obuhvaća sve što iziskuje raspravu, odložih rad o Demostenu koji sam imao u rukama i obećah da ću uraditi kako si bio odlučio, i dovršivši ga, ispunjavam obećanje."

Cum vero cupere te animadvertissem, ut separatim de Thucydidis historia commentarios conficerem, in quibus quae in illo animadversione digna sunt, omnia persequerer, eo libro, quem de Demosthene tum in manibus habebam, reiecto, ${ }^{31}$ pollicitus sum tuae me voluntati obemperaturum. nunc vero, re confecta, quod tunc promiseram, tibi persolvo.

31 U rukopisu prethode riječi in aliud tempus, podcrtane Manuzijevom rukom (fol. 1 verso). 
„Kad sam primijetio tvoju želju da izradim posebne komentare Tukididove Povijesti, u kojima bih zapisao sve što je u njemu vrijedno pozornosti, odložih onu knjigu o Demostenu, koju sam tada imao u rukama i obećah da ću se pokoriti tvojoj volji. Sada pak, dovršivši posao, ispunjavam što sam ti nekoć bio obećao."

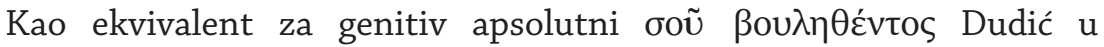
latinskom donosi vremensku rečenicu kojoj je dodan glagolski oblik animadvertissem za koji nema povoda u originalu. Genitiv apsolutni može se prevesti vremenskom rečenicom kojom bi se zadržalo isto značenje, a

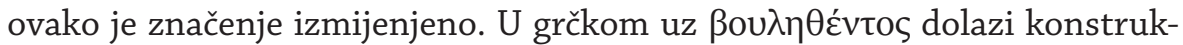
cija akuzativa s infinitivom, a u latinskom uz cupere zahtjevna rečenica.

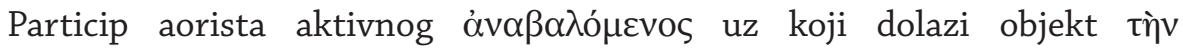
$\pi \rho \alpha \gamma \mu \alpha \tau \varepsilon i ́ \alpha v$ Dudić pretvara u ablativ apsolutni eo libro reiecto, kojem dodaje i zamjenicu is. Isti postupak slijedi u nastavku rečenice gdje particip $\tau \varepsilon \lambda \varepsilon ́ \sigma \alpha \varsigma$, koji se odnosi na neizrečeni subjekt rečenice i dopunjen je

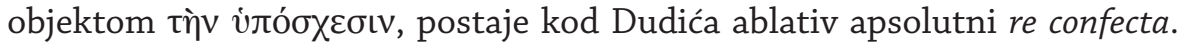
Particip aorista aktivnog nije imao ekvivalentni oblik u latinskom, ali se participom perfekta pasivnog mogla izraziti pasivna svršena radnja. Ablativ apsolutni re confecta posvjedočen je kod Cezara (Caes. Civ. 2.13.2) te je upotreba tog izraza najvjerojatnije posljedica čitanja klasične lektire.

Particip aorista pasivnog mogao se zamijeniti latinskim participom perfekta pasivnog, te je primjerice u prijedložnom izrazu غ̉v toĩs

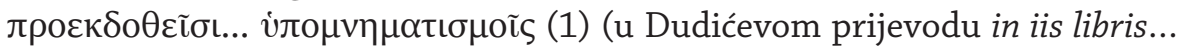

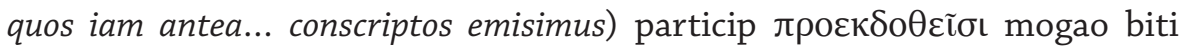
preveden participima editis ili emissis. Čini se da čak i kad nije trebao proširivati prijevod, Dudić je ipak dodavao pokoji glagolski oblik koji nije bio motiviran izvornikom.

\subsection{Leksik}

Već su Rimljani bili svjesni leksičkih razlika između grčkog i latinskog. Ponekad su proširenja potrebna da se objasni grčki pojam za koji nema

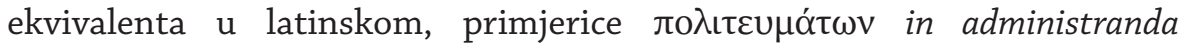

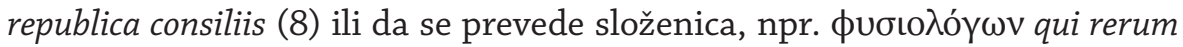
natura constantium philosophiam profiterentur (3). Umjesto spomena grčkog boga Zeusa, Dudić koristi sane za $\mu$ ò $\Delta$ ía (2). Dudić koristi grčke riječi ako

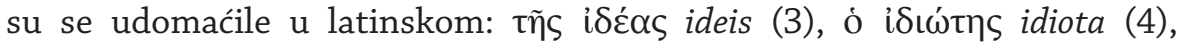

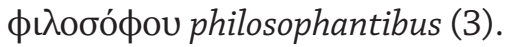


U Dudićevom latinskom vokabularu primjećuje se utjecaj rimskih

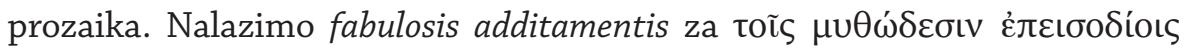
(7), a riječ additamentum se pojavljuje najčešće kod Cicerona (tri od ukupno šest pojava u korpusu rimske književnosti, ostale su kod Apuleja, u Senekinim pismima i Vulgati). ${ }^{32} \mathrm{U}$ istom odlomku nalazimo ludificationes za yoךtcías. Riječ ludificatio upotrebljavaju samo Ciceron (Cic. Sest. 35, 75) i Livije $(6.27 .6,7.39 .4) .{ }^{33}$ Ciceron je jedan od mogućih izvora rijetke riječi

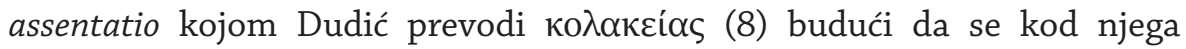
pojavljuje najviše puta (jedanput su je upotrijebili Amijan Marcelin, Plaut, Plinije Mlađi i Seneka u proznom spisu De ira). Dudić je na ovom mjestu mogao upotrijebiti i mnogo češću riječ adulatio. U svakom slučaju možemo zaključiti da je Dudić pisao pod utjecajem rimskih proznih autora, što nije neočekivano kod humanista koji i sam piše prozu. ${ }^{34}$ Samo na osnovu navedenih primjera ne bismo mogli ustvrditi da je Dudić smatrao Cicerona posebnim stilskim uzorom budući da nijedna riječ nije potvrđena samo kod Cicerona (kao što je recimo slučaj s Cezarom u 6.2 i 6.3). Ipak, jedna Dudićeva opaska daje naslutiti da mu je iznad svih ostalih rimskih autora bilo osobito važno oponašati Cicerona: uz riječ penitus Dudić u marginalijama uz posvetu Olahu bilježi non è Ciceroniano onde forse e meglio dire accuratius... (fol. 4 bis recto). Ova je opaska važna kao dokaz da je Dudić svjesno nasljedovao antičkog uzora.

Kao primjer Manuzijevog sažimanja Dudićevih riječi koje spominje

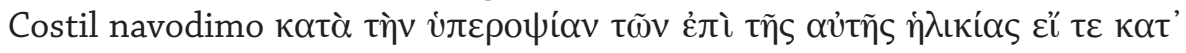

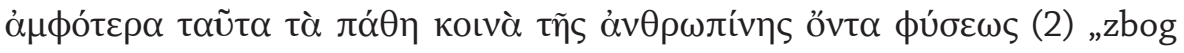
oholosti prema svome dobu ili zbog jednog i drugog, što je zajednička bolest ljudske prirode" sažeto u suam aetatem aspernati: quo plerique homines vitio laborant „prezreli su svoje doba: bolest od koje boluje većina ljudi” iz Dudićevog sive id propterea faciant, quod sua tempora contemptui habeant sive quod utroque, hoc est communi hominum natura sunt vitio praediti "Ili to čine zato što svoje doba drže prezrenim ili zbog jednoga i drugoga, a ljudi po prirodi imaju tu zajedničku bolest" (fol. 2 recto). Dudićevo neque sane illius quoque rei non memineramus „nismo, doista, zaboravili ni to” kao prijevod za

32 Podaci dobiveni pretraživanjem na Perseusu (http://perseus.uchicago.edu/latin.html). Pristupljeno 1. 10. 2018.

33 Logeion navodi natuknicu iz Lewis-Shortovog rječnika. Online izdanje na http://logeion. uchicago.edu/index.html\#ludificatio. Pristupljeno 1. 10. 2018.

34 Smatramo da bi jedna jedina pojava komediografa Plauta mogla biti rezultat slučajnosti. 


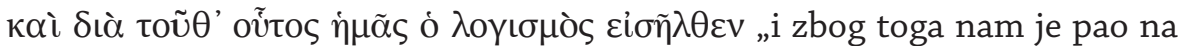
pamet ovaj zaključak" (2), Manuzio je promijenio u Neque vero illud nos fugit „i nije nam promaklo”, možda i po uzoru na Cicerona, a ne samo iz želje za skraćivanjem. ${ }^{35}$ Poneke Manuzijeve izmjene ipak nisu kraće, npr. $\tau \tilde{\omega} v \hat{\alpha} \lambda \lambda \omega v$ $\phi \iota \lambda 0 \lambda{ }^{\prime} \gamma \omega v$ „od ostalih filologa” (2) postaje qui elegantis doctrinae studio tenentur „koji se bave izučavanjem lijepoga” umjesto Dudićevog qui sunt elegantis doctrinae amatores „koji vole izučavati što je lijepo” (fol. 2 verso). Napominjemo i da nije svaka Manuzijeva ispravka ušla u tiskano izdanje, npr. ostalo je izvorno et plausibile in vulgus „vrijedno javne pohvale” (fol. 3. verso), mada se u rukopisu nalazila i Manuzijeva ispravka. Na nekoliko se mjesta tiskano izdanje ne poklapa ni s Dudićevom, ni Manuzijevom rukopisnom verzijom: tiskano qui in dogmatibus dissentiunt „koji se razlikuju u mišljenjima" stoji umjesto Dudićeva prijevoda qui in ipsis placitis inter se discrepant, „koji se u svojim mišljenjima međusobno razilaze” i Manuzijeva rukopisnog prepravljanja u quorum sententiae discrepant „čija se mišljenja mimoilaze" (fol. 3 verso). Zamislivo je da su Dudić i Manuzio nakon rada na ovom rukopisu, a prije tiskanja prijevoda, prošli tekst još jednom i smislili nova rješenja.

\section{Dudić u kontekstu humanističkog prevođenja}

Brenda Hosington ukratko prikazuje nekoliko autora humanističkih traduktoloških rasprava. Navest ćemo ovdje one čija djela kronološki prethode Dudiću. U petnaestom je stoljeću Alonso iz Cartagene smatrao da se nipošto ne smije iskriviti riječi izvornika, dok je potpuno oprečan stav zauzeo utjecajniji Leonardo Bruni koji je naglašavao važnost retorike, stila i elokvencije, a Giannozzo Manetti zalagao se za zlatnu sredinu, 'medium et tutum', kod prevođenja filozofskih djela (Hosington 2014: 127-128). Joachim Périon bio je nadahnut već spomenutim Ciceronovim raspravama De finibus bonorum et malorum i De optimo genere oratorum te je u djelu Cormorriaceni de optimo genere interpretandi commentarii objavljenom 1540. naglašavao da prevodiočeva sposobnost izražavanja na jeziku prijevoda ključna za prenošenje misli iz izvornika (Hosington 2014: 128-129). Laurence Humphrey se u raspravi Interpretatio linguarum seu de ratione convertendi et explicandi autores tam sacros quam prophanos, tiskanoj 1559,

\footnotetext{
35 Lewis-Shortov rječnik na Logeionu donosi po natuknicom fugio B2b izraz res me fugit te niz primjera iz Cicerona za tu upotrebu tog glagola: quem res nulla fugeret, Cic. Rep. 2, 1, potom Rep. 2, 12, Fin. 4, 23, 63, Verr. 2, 4, 12, § 27 (Logeion 2018).
} 
pozivao na Cicerona, Horacija i Kvintilijana, inzistirao na poznavanju retorike, te dopuštao gramatičke promjene poput zamjene jedne vrste riječi drugom (Hosington 2014: 129). Na tragu spomenutog Alonsa iz Cartegene nalazimo koparskog prevodioca Andreu Diva, čiji je stil okarakteriziran kao izrazito doslovan (Gantar 2016, Jovanović 2016). Divov primjer pokazuje da je i prevođenje ad verbum imalo svoju publiku čak i u vrijeme kad je renesansa bila u punom zamahu (15-16. st.). ${ }^{36}$ Dudićev pristup svakako je bliži Brunijevom i Humphreyevom nego Divovom. Dopuštao si je promjene koje je i Humphrey smatrao prihvatljivima, a vokabular preuzet od klasika rimske proze na tragu je Brunijeva stava da je važno elegantno izražavanje na ciljanom jeziku. Ne može se reći da se Dudić strogo pridržavao originala te povremeno nailazimo i na sitnija proširivanja izvornika. Smatramo da su ta proširivanja nastala prvenstveno iz želje za oponašanjem rimskih uzora, a potom iz želje da se pomogne čitaocu, te da nisu išla nauštrb smisla teksta. Dudić je u uvodu najavio da će zadržati izvorni smisao teksta i to je i ostvario.

\section{Zaključak}

Budući da se Dionizije Halikarnašanin bavio Tukididovim sadržajem i stilom - a naposljetku i jer je poznavao grčki jezik bolje nego ijedan humanist - prijevod njegova ogleda na latinski služio je kao pomoć za svako filološko bavljenje Tukididom. Manuzijevo izdanje i Vallin prijevod Tukidida pokazuju da je među humanistima postojalo zanimanje za Tukidida, a broj izdanja Dudićevog prijevoda pokazuje da je bilo interesa i za sekundarnu literaturu o Tukididu iz pera još jednog uglednog antičkog povjesničara. Dudić je svojim suvremenicima prenio Dionizijeva razmišljanja u duhu rimske proze. Držao se pravila klasične latinske sintakse. Vidljiv je utjecaj rimskih prozaika čiji stil oponaša dok interpretira Dionizija iz Halikarnasa. Aludiranje na Cicerona u predgovoru i komentar u marginalijama rukopisa (non è Ciceroniano...) navode na zaključak da je Dudiću bio vrlo dobro poznat opus najvećeg rimskog govornika, što ne iznenađuje budući da se za vrijeme boravka u Padovi intenzivno družio s talijanskim i poljskim humanistima koji su temeljito proučavali Cicerona, a neki i izdavali njegova

36 Štoka navodi sva izdanja Divovih prijevoda Homera (Štoka 2016). O Divovom pijevodu Homera kao pomoći onima koji znaju latinski, ali ne znaju grčki, piše Neven Jovanović (Jovanović 2016). 
djela. Rečeni komentar vrijedan je kao dokaz da je Dudić svjesno birao riječi koje će upotrijebiti i svjesno imitirao Cicerona. Kao prevodilac Dudić je blizak razmišljanjima Leonarda Brunija i njegovih sljedbenika.

\section{Literatura}

Almási, Gábor (2009) The Uses of Humanism, Brill, Leiden i Boston.

Cochrane, Eric (1981) Historians and Historiography in the Italian Renaissance, University of Chicago Press, Chicago.

Costil, Pierre (1935) André Dudith humaniste hongrois 1533-1589, Les belles lettres, Paris.

Dessau, Hermann (1897) Prosopographia imperii romani, Vol. 2, BerlinBrandenburgische Akademie der Wissenschaften, Berlin.

De Jonge, Casper (2008) Between Grammar and Rhetoric. Dionysius of Halicarnassus on Language, Linguistics and Literature, Brill, Leiden i Boston.

Dionysius Halicarnassensis (1560) De Thucydidis historia iudicium, Andrea Duditio Pannonio interprete, [Paolo Manuzio], Venetiis.

Facca, Danilo, Lepri, Valentina (2016) „In the Shadow of Cicero: An Early Modern Think-Tank at the Academy of Zamość", De amicitia: Transdisciplinary Studies in Friendship, ur. Katarzyna Marciniak and Elżbieta Olechowska, Varšava, 79-89.

Fornaro, Sotera (1997) „Dionysios von Halikarnassos, Der neue Pauly. Enzyklopädie der Antike", 3, ur. Hubert Cancik, Helmuth Schneider, Stuttgart i Weimar.

Fromentin, Valérie (2001) „Denys d'Halicarnasse, historien grec de Rome”, Actes du 11ème colloque de la Villa Kérylos à Beaulieu-sur-Mer les 13 \& 14 octobre 2000", Paris, 123-142.

Gabba, Emilio (1991) Dionysius and the True History of Archaic Rome, University of California Press, Berkeley.

Gantar, Kajetan (2016) „Andreas Divus iz Kopra - prevajalec Homerja”, Divina: Andreas Divus Iustinopolitanus, ur. Gregor Pobežin i Peter Štoka, Koper, 19-26.

Grayson, Christopher (1975) „Did Xenophon Intend to Write History?”, The Ancient Historian and his Materials. Essays in Honour of C. E. Stevens on his Seventieth Birthday, ur. Barbara Levick, Gregg, Farnborough, 31-43. 
Grendler, Marcella (1980) „A Greek Collection in Padua: The Library of Gian Vincenzo Pinelli (1535-1601)", Renaissance Quarterly 33, 3, 386-416.

Grube, George (1950) „Dionysius of Halicarnassus on Thucydides”, Phoenix 4, 95-110.

Hosington, Brenda M. (2014) „Translation and Neo-Latin”, Brill's Encyclopaedia of the Neo-Latin World, ur. Philip Ford, Jan Bloemendal i Charles Fantazzi, Brill, Leiden, 127-140.

Ianziti, Gary (2012) Writing History in Renaisance Italy: Leonardo Bruni and the Uses of the Past, Harvard University Press, Cambridge i London.

Irwin, Elizabeth (2015) „Dionysius of Halicarnassus' On Thucydides and Thucydides' rhetoric of the episodic", Tecendo narrativas: unidade $e$ episódio na literatura grega antiga, ed. Christian Werner, São Paulo, 121-199.

Jacoby, Felix (1957) „Dionysios von Halikarnassos”, Die Fragmente der griechischen Historiker, Brill, Leiden.

Jovanović, Neven (2016) „Andrea Divo i čitanje Ilijade”, Divina: Andreas Divus Iustinopolitanus, ur. Gregor Pobežin i Peter Štoka, Koper, 5579.

Jurić Šime (2018) „Andrija Dudić”, Hrvatski biografski leksikon, ur. Nikša Lučić, Filip Hameršak, Iva Mandušić, Martina Kokolari, online na http://hbl.lzmk.hr/clanak.aspx?id=5579, pristupljeno 9. 10. 2018.

Logeion (2018) www.logeion.uchicago.edu pristupljeno 1. 10. 2018.

Manea-Grgin, Castilia (2010) „Humanist i zagrebački biskup Nicolaus Olahus (Nikola Olah, Nicolae Valahul ili Românul, 1543-1548) i njegova korespondencija sa Stjepanom Brodarićem", Radovi Zavoda za hrvatsku povijest Filozofskoga fakulteta Sveučilišta u Zagrebu, 42, 231-261.

Meister, Klaus (2016) „The Fall of the Roman Republic: Sallust's Reading of Thucydides", Thucydides and Political Order Lessons of Governance and the History of the Peloponnesian War, ur. Christian Thauer i Christian Wendt, Palgrave Macmillan, London, 131-150.

Meschini, Anna (1981) Michele Sofianòs, Liviana editrice, Padova.

Nicolai, Roberto (2006) „Thucydides Continued”, Brill's Companion to Thucydides, ur. Antonis Tsakmakis, Brill, Leiden i Boston, 693-720. 
Pade, Marianne (2003) „Thucydides”, Catalogus Translationum et Commentariorum: Mediaeval and Renaissance Latin Translations and Commentaries, Vol. VIII, ur. Virginia Brown, James Hankins i Robert A. Kaster, Catholic University of America Press, Washington D.C., 103-181.

Pade, Marianne (2015) „The Renaissance Scholarship, Criticism, and Education", A Handbook of the Reception of Thucydides, ur. Christine Lee i Neville Morley, Wiley Blackwell, Malden i Oxford, 26-42.

Parker, Victor (2001) „Ephorus and Xenophon on Greece in the Years 375372 BC", Klio, 83, 353-368.

Perseus Digital Library (2018) http://perseus.uchicago.edu/latin.html. Pristupljeno 1. 1. 2018.

Peter, Hermannus ( $\left.{ }^{2} 1914\right)$ Historicorum Romanorum reliquiae, Vol. 1, Teubner, Leipzig.

Pritchett, Kendrick (1975) Dionyisus of Halicarnassus: On Thucydides, University of California Press, Berkeley, Los Angeles i London.

Reardon, Brian P. (1971) Courants littéraires grecs des IIe et IIIe siècles après J.-C., Annales littéraires de l'Université de Nantes, 3, Les Belles Lettres, Paris.

Riedinger, Jean-Claude (1991) Étude sur les Helléniques. Xénophon et l'histoire, Les Belles Lettres, Paris.

Schwartz, Eduard (1905) „Dionysios von Halikarnassos”, Paulys RealEncyclopädie der classischen Altertumwissenschaft 5, ur. Georg Wissowa, Stuttgart, 934-961.

Štoka, Peter (2016) „Značilnosti nastanka latinskih književnih izdaj prevodov Homerja v 16. in 17. stoletju", Divina: Andreas Divus Iustinopolitanus, ur. Gregor Pobežin i Peter Štoka, Koper, 137-166.

Usher, Stephen (1974) Dionysius of Halicarnassus, The Critical Essays, Vol. 1. (ur.), The Loeb Classical Library, London, 462-633.

Wisse, Jakob (2001) „Greeks, Romans, and the Rise of Atticism”, Greek Literature in the Roman Period and in Late Antiquity Greek Literature, ur. Gregory Nagy, London, 65-82. 
SUMMARY

Josip Parat and Petra Šoštarić LATIN TRANSLATION OF DIONYSIUS OF HALICARNASSUS' DE
THUCYDIDIS HISTORIA IUDICIUM BY ANDREAS DUDITHIUS

Thucydides, one of the greatest Greek historians, has been admired for centuries after writing his account of the Peloponnesian war. His critics were fewer than his admirers, but he was not exempt from critique. Dionysius of Halicarnassus wrote the treatise

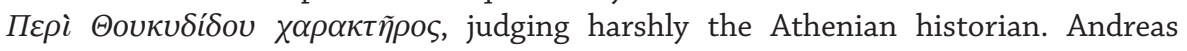
Dudithius, a Renaissance scholar and diplomat, translated the treatise into Latin, encouraged by his friend Paolo Manuzio who published the translation in 1560 . Dudithius dedicated the translation to his sponsor Nicolaus Olahus, bishop of Estergom and a historian. In the preface, Dudithius states that his translation will not be ad verbum. In his use of Latin he emulates classical models. In the context of humanist translation Dudithius is closer to the learned and influential Leonardo Bruni than to the adherents of the ad verbum style such as Andreas Divus and Alonso of Cartagena.

Keywords: Dionysius of Halicarnassus; Thucydides; Andreas Dudithius; reception of classical antiquity; humanism, Greek-to-Latin translations 